\title{
Neddylation and anti-tumor immunity
}

Research Perspective

\author{
Xiaoguang Wang ${ }^{1}$, Scott Best ${ }^{2}$ and Alexey V. Danilov ${ }^{1}$ \\ ${ }^{1}$ Department of Hematology and Hematopoietic Stem Cell Transplant, City of Hope National Medical Center, Duarte, CA, USA \\ ${ }^{2}$ Molecular and Cellular Biology, University of Washington, Seattle, WA, USA \\ Correspondence to: Alexey V. Danilov, email: adanilov@coh.org \\ Keywords: neddylation; T cell; pevonedistat
}

Received: June 10,2021 Accepted: June 21, 2021

Published: October 12, 2021

Copyright: @ 2021 Wang et al. This is an open access article distributed under the terms of the Creative Commons Attribution License (CC BY 3.0), which permits unrestricted use, distribution, and reproduction in any medium, provided the original author and source are credited.

\begin{abstract}
Contrary to chemotherapy, novel targeted therapies are associated with diverse immunomodulatory effects. Nedd8 is a small ubiquitin-like modifier that is involved in regulation of protein degradation. Neddylation is a promising target in cancer. Pevonedistat, a small molecule inhibitor of the Nedd8-activating enzyme, demonstrates pre-clinical activity in multiple tumor types. Recent studies have revealed that neddylation is important in immunity. We and others have shown that interfering with neddylation causes downstream immunomodulatory effects potentially leading to enhanced anti-tumor immunity. Thus, Nedd8 is a promising target in immuno-oncology.
\end{abstract}

The ubiquitin-proteasome system (UPS) is a common pathway which controls degradation of unwanted or misfolded proteins in cells. Proteins targeted for degradation are labeled with ubiquitin chains by E3 ubiquitin ligases [1]. The Cullin-RING E3 ubiquitin ligases (CRLs) represent the largest family of E3 ligases, which contribute approximately $20 \%$ of UPS-mediated protein degradation [2]. Targeting protein degradation pathway has precedence in the clinic. Bortezomib, carfilzomib and ixazomib are proteasome inhibitors which received regulatory approvals in the therapy of multiple myeloma. Lenalidomide and pomalidomide modulate Cereblon, part of an E3 ligase complex, resulting in increased secretion of IL-2 by T cells, a shift towards the Th1 phenotype and improved immune synapse formation [3]. Moreover, lenalidomide was shown to enhance the function of chimeric antigen receptor $\mathrm{T}$ cells [4].

The conjugation of the ubiquitin-like modifier NEDD8 to Cullins (neddylation) is essential for the conformational change and subsequent ubiquitination of CRL (Cullin RING ligase) substrates [5]. As a posttranslational modification process, neddylation is a threestep sequential enzymatic reaction: 1. NEDD8 activation by the E1 NEDD8-activating enzyme (NAE, NAE1/ UBA3 heterodimer) in an ATP-dependent manner; 2. NEDD8 transfer to the E2 NEDD8-conjugating enzymes (UBC12 and UBE2F) via a thioester linkage; 3. NEDD8 conjugation to cullin activates the ubiquitin ligase activity of the CRL [6, 7]. Pevonedistat is a small molecule which covalently adducts with NEDD8, leading to effective inhibition of NAE via competitive binding. Consequently, NEDD8 is prevented from conjugation to CRLs, thus leading to CRL deactivation and accumulation of CRLdependent substrates [8]. As a first-in-class NAE inhibitor, pevonedistat demonstrated pre-clinical and early clinical efficacy across multiple tumor types [9-14]. Furthermore, we and others have reported additive cytotoxic activity of NAE inhibition in combination with chemotherapeutic and targeted agents [15-20]. Pevonedistat has entered clinical trials in solid tumors and hematologic malignancies. Our group is conducting a Phase I clinical trial investigating pevonedistat in non-Hodgkin lymphoma (NCT03479268).

Recent reports have implicated neddylation in regulation of immune cell function, including proliferation, maturation, effector cell function and signal transduction [21-25]. Meanwhile, pharmacologic and genetic manipulation of the neddylation pathway has been shown to modulate T-cell mediated immune responses [26]. A significant body of literature suggests that neddylation regulates T-cell functionality. In a pivotal study, genetic knockdown of the Nedd8-conjugating enzyme Ubc12 in murine $\mathrm{CD}^{+} \mathrm{T}$ cells led to diminished proliferation, skewed Th1/Th2 differentiation and reduced cytokine production [21]. In vivo treatment with pevonedistat was shown to have comparable effects in a malaria murine model, where UBA3 deficiency significantly 
compromised survival, activation, and proliferation of CD4 T cells and impaired Th1/Tfh differentiation [22]. Similarly, downmodulation of sensitive to apoptosis gene (SAG), regulator of Cullin neddylation, reduced T-cell activation, proliferation, and cytokine release in murine $\mathrm{T}$ cells [23]. Recently, our group has shown that in vitro exposure to pevonedistat downregulated activation of proximal T-cell receptor (TCR) signaling, accompanied by suppression of NF- $\mathrm{kB}$-regulated genes and IL-2 signaling in $\mathrm{T}$ cells derived from patients with chronic lymphocytic leukemia (CLL) [24]. However, we also found that targeting neddylation may exert immune modulation that ultimately leads to enhanced anti-tumor effects. Specifically, we demonstrated that NAE inhibition with pevonedistat suppressed induction of FoxP3-positive CD4 Tregs in in vitro conditions. This result was confirmed in immunized mice [24]. Furthermore, we have observed increased T-cell polarization towards Th1 phenotype in vitro and in vivo, accompanied by an increase of IFN $\gamma$ production. Our results are partially supported by Friend et al who observed that CRLs suppress TCR signaling and IL-2 production in murine T-cell hybridomas, a phenomenon reversed by pevonedistat [25].

Although pevonedistat may suppress the ability of dendritic cells to stimulate murine and human allogeneic T-cell responses [27], treatment with pevonedistat was shown to significantly inhibit infiltration of immune suppressor cells, including tumor-associated macrophages (TAMs) and myeloid derived suppressor cells (MDSCs), and promoted CD8 $\mathrm{T}$ cell infiltration in lung cancer models [28].

Immune checkpoint (e.g., PD-1, CTLA-4) has become an important target in cancer. There is paucity of data as to how neddylation and other UPS components regulate expression, turnover and function of these molecules. We have found that targeting NAE with pevonedistat significantly enhanced CTLA-4 expression in human $\mathrm{T}$ cells [24]. The mechanism for this is poorly understood but may depend on NAE-mediated control of several key signaling pathways. CTLA-4 is positively regulated by the transcription factor GATA3 [29]. Proteasome inhibition was shown to induce GATA3, upregulate CTLA-4 expression and thereby efficiently suppress the proliferation of CD4 T cells in vitro [29]. A recent study found that SKP1-Cul1-F-box E3 ligase complex induces degradation of GATA3 in a GSK3dependent manner [30], and targeting this complex may therefore lead to enhanced expression of CTLA-4. On the other hand, our data shows that pevonedistat markedly increases HIF-1 $\alpha$ expression in CD3/28-stimulated T cells [24], a finding consistent with the fact that ubiquitination of HIF- $1 \alpha$ is mediated by VHL-Cul2-EloBC E3 ligase. HIF- $1 \alpha$ is critical to metabolic transition to glycolysis, a process indispensable in T-cell proliferation and effector functions [31]. Loss of HIF-1 $\alpha$ in CD8 T cells was shown to reduce activation, tumor infiltration and tumor cell killing, and alter tumor vascularization [32]. By contrast, VHL-deficient cytotoxic $\mathrm{T}$ lymphocytes displayed enhanced control of persistent viral infection and neoplastic growth via HIFs [33]. Checkpoint receptors, including TIM3, PD-1, CTLA-4 and LAG-3, were also downregulated in CD8 $\mathrm{T}$ cells deficient in HIF-1 $\alpha$, and thus it is possible that enhanced CTLA-4 expression observed by us may be in part mediated by NAE interference with HIF-1 $\alpha$ signaling pathway [32].

Genetic depletion of key neddylation pathway enzymes or pevonedistat treatment was also shown to markedly elevate PD-L1 expression in gliomas, in part due to a block in degradation of MYC protein [18, 34]. Furthermore, inactivation of cullin 3-SPOP E3 ligases blocked degradation of PD-L1, causing increased PD-L1 levels and reduced numbers of tumorinfiltrating lymphocytes in mouse tumors and in primary human prostate cancer specimens [35]. While PD-L1 induction attenuated $\mathrm{T}$ cell-mediated killing in this model, concurrent targeting of NAE and PD-L1 restored anti-tumor immunity. Targeting NAE may also enhance tumor antigenicity. Thus, cancer cells exhibiting enhanced microsatellite instability (MSI) were dependent on neddylation to clear misfolded protein aggregates resulting from destabilizing mutations [17]. In these cells, treatment with pevonedistat induced immunogenic cell death when PD-1 was blocked. These studies pave the way for rationally designed therapeutic strategies employing a neddylation inhibitor and a checkpoint inhibitor. The effects of concurrent targeting neddylation and CTLA-4 and other immune checkpoint molecules have not been investigated thus far.

In sum, a significant body of literature highlights direct anti-tumor effects of pevonedistat, firmly establishing neddylation as a therapeutic target in cancer. Provocative new data uncover a hitherto poorly understood immunomodulatory function of neddylation, with a potential to redefine its place in immuno-oncology. Such advances are highly relevant in the current age of cancer therapeutics, as they open avenues to enhance efficacy of existing therapies as well as develop novel mechanistic approaches to boost anti-tumor immunity.

\section{CONFLICTS OF INTEREST}

A.V.D. is a Leukemia and Lymphoma Society Clinical Scholar (\#2319-19). This was work supported by the American Society of Hematology Bridge Award, and the NIH/NCI R01 CA244576 (to AVD).

\section{FUNDING}

A.V.D. has received consulting fees from Abbvie, AstraZeneca, BeiGene, Genentech, Pharmacyclics and TG Therapeutics and has ongoing research funding from AstraZeneca, Bayer Oncology, Bristol Meyers Squibb, 
MEI Pharma, SecuraBio, TG Therapeutics and Takeda Oncology.

\section{REFERENCES}

1. Hershko A. The ubiquitin system for protein degradation and some of its roles in the control of the cell division cycle. Cell Death Differ. 2005; 12:1191-97. https://doi. org/10.1038/sj.cdd.4401702. [PubMed]

2. Soucy TA, Smith PG, Milhollen MA, Berger AJ, Gavin JM, Adhikari S, Brownell JE, Burke KE, Cardin DP, Critchley $\mathrm{S}$, Cullis CA, Doucette A, Garnsey JJ, et al. An inhibitor of NEDD8-activating enzyme as a new approach to treat cancer. Nature. 2009; 458:732-36. https://doi.org/10.1038/ nature07884. [PubMed]

3. Ramsay AG, Johnson AJ, Lee AM, Gorgün G, Le Dieu R, Blum W, Byrd JC, Gribben JG. Chronic lymphocytic leukemia $\mathrm{T}$ cells show impaired immunological synapse formation that can be reversed with an immunomodulating drug. J Clin Invest. 2008; 118:2427-37. https://doi. org/10.1172/JCI35017. [PubMed]

4. Wang X, Walter M, Urak R, Weng L, Huynh C, Lim L, Wong CW, Chang WC, Thomas SH, Sanchez JF, Yang L, Brown CE, Pichiorri F, et al. Lenalidomide Enhances the Function of CS1 Chimeric Antigen Receptor-Redirected T Cells Against Multiple Myeloma. Clin Cancer Res. 2018; 24:106-19. https://doi.org/10.1158/1078-0432.CCR-170344. [PubMed]

5. Petroski MD, Deshaies RJ. Function and regulation of cullin-RING ubiquitin ligases. Nat Rev Mol Cell Biol. 2005; 6:9-20. https://doi.org/10.1038/nrm1547. [PubMed]

6. Enchev RI, Schulman BA, Peter M. Protein neddylation: beyond cullin-RING ligases. Nat Rev Mol Cell Biol. 2015; 16:30-44. https://doi.org/10.1038/nrm3919. [PubMed]

7. Watson IR, Irwin MS, Ohh M. NEDD8 pathways in cancer, Sine Quibus Non. Cancer Cell. 2011; 19:168-76. https:// doi.org/10.1016/i.ccr.2011.01.002. [PubMed]

8. Brownell JE, Sintchak MD, Gavin JM, Liao H, Bruzzese FJ, Bump NJ, Soucy TA, Milhollen MA, Yang X, Burkhardt AL, Ma J, Loke HK, Lingaraj T, et al. Substrate-assisted inhibition of ubiquitin-like proteinactivating enzymes: the NEDD8 E1 inhibitor MLN4924 forms a NEDD8-AMP mimetic in situ. Mol Cell. 2010; 37:102-11. https://doi.org/10.1016/j.molcel.2009.12.024. [PubMed]

9. Soucy TA, Smith PG, Rolfe M. Targeting NEDD8-activated cullin-RING ligases for the treatment of cancer. Clin Cancer Res. 2009; 15:3912-16. https://doi.org/10.1158/1078-0432. CCR-09-0343. [PubMed]

10. Shah JJ, Jakubowiak AJ, O'Connor OA, Orlowski RZ, Harvey RD, Smith MR, Lebovic D, Diefenbach C, Kelly K, Hua Z, Berger AJ, Mulligan G, Faessel HM, et al. Phase I Study of the Novel Investigational NEDD8-Activating Enzyme Inhibitor Pevonedistat (MLN4924) in Patients with Relapsed/Refractory Multiple Myeloma or Lymphoma. Clin
Cancer Res. 2016; 22:34-43. https://doi.org/10.1158/10780432.CCR-15-1237. [PubMed]

11. Swords RT, Erba HP, DeAngelo DJ, Bixby DL, Altman JK, Maris M, Hua Z, Blakemore SJ, Faessel H, Sedarati F, Dezube BJ, Giles FJ, Medeiros BC. Pevonedistat (MLN4924), a Firstin-Class NEDD8-activating enzyme inhibitor, in patients with acute myeloid leukaemia and myelodysplastic syndromes: a phase 1 study. Br J Haematol. 2015; 169:534-43. https://doi. org/10.1111/bjh.13323. [PubMed]

12. Godbersen JC, Humphries LA, Danilova OV, Kebbekus PE, Brown JR, Eastman A, Danilov AV. The Nedd8-activating enzyme inhibitor MLN4924 thwarts microenvironmentdriven NF- $\mathrm{KB}$ activation and induces apoptosis in chronic lymphocytic leukemia B cells. Clin Cancer Res. 2014; 20:1576-89. https://doi.org/10.1158/1078-0432.CCR-130987. [PubMed]

13. Luo Z, Yu G, Lee HW, Li L, Wang L, Yang D, Pan Y, Ding C, Qian J, Wu L, Chu Y, Yi J, Wang X, et al. The Nedd8activating enzyme inhibitor MLN4924 induces autophagy and apoptosis to suppress liver cancer cell growth. Cancer Res. 2012; 72:3360-71. https://doi.org/10.1158/0008-5472. CAN-12-0388. [PubMed]

14. Milhollen MA, Traore T, Adams-Duffy J, Thomas MP, Berger AJ, Dang L, Dick LR, Garnsey JJ, Koenig E, Langston SP, Manfredi M, Narayanan U, Rolfe M, et al. MLN4924, a NEDD8-activating enzyme inhibitor, is active in diffuse large B-cell lymphoma models: rationale for treatment of NF\{kappa\}B-dependent lymphoma. Blood. 2010; 116:1515-23. https://doi.org/10.1182/blood-2010-03-272567. [PubMed]

15. Smith PG, Traore T, Grossman S, Narayanan U, Carew JS, Lublinksky A, Kuranda M, Milhollen M. Azacitidine/ Decitabine Synergism with the NEDD8-Activating Enzyme Inhibitor MLN4924 in Pre-Clinical AML Models. Blood. 2011; 118:578. https://doi.org/10.1182/blood. $\underline{\mathrm{V} 118.21 .578 .578 .}$

16. Nawrocki ST, Kelly KR, Smith PG, Keaton M, Carraway H, Sekeres MA, Maciejewski JP, Carew JS. The NEDD8activating enzyme inhibitor MLN4924 disrupts nucleotide metabolism and augments the efficacy of cytarabine. Clin Cancer Res. 2015; 21:439-47. https://doi.org/10.1158/10780432.CCR-14-1960. [PubMed]

17. McGrail DJ, Garnett J, Yin J, Dai H, Shih DJH, Lam TNA, Li Y, Sun C, Li Y, Schmandt R, Wu JY, Hu L, Liang Y, et al. Proteome Instability Is a Therapeutic Vulnerability in Mismatch Repair-Deficient Cancer. Cancer Cell. 2020; 37:371-86.e12. https://doi.org/10.1016/j.ccell.2020.01.011. [PubMed]

18. Zhou S, Zhao X, Yang Z, Yang R, Chen C, Zhao K, Wang W, Ma Y, Zhang Q, Wang X. Neddylation inhibition upregulates PD-L1 expression and enhances the efficacy of immune checkpoint blockade in glioblastoma. Int J Cancer. 2019; 145:763-74. https://doi.org/10.1002/ijc.32379. [PubMed]

19. Paiva C, Godbersen JC, Berger A, Brown JR, Danilov AV. Targeting neddylation induces DNA damage and checkpoint activation and sensitizes chronic lymphocytic leukemia B 
cells to alkylating agents. Cell Death Dis. 2015; 6:e1807. https://doi.org/10.1038/cddis.2015.161. [PubMed]

20. Paiva C, Godbersen JC, Rowland T, Danilova OV, Danes C, Berger A, Danilov AV. Pevonedistat, a Nedd8-activating enzyme inhibitor, sensitizes neoplastic B-cells to death receptor-mediated apoptosis. Oncotarget. 2017; 8:2112839. https://doi.org/10.18632/oncotarget.15050. [PubMed]

21. Jin HS, Liao L, Park Y, Liu YC. Neddylation pathway regulates T-cell function by targeting an adaptor protein Shc and a protein kinase Erk signaling. Proc Natl Acad Sci U S A. 2013; 110:624-29. https://doi.org/10.1073/ pnas.1213819110. [ubMed]

22. Cheng Q, Liu J, Pei Y, Zhang Y, Zhou D, Pan W, Zhang J. Neddylation contributes to CD4+ T cell-mediated protective immunity against blood-stage Plasmodium infection. PLoS Pathog. 2018; 14:e1007440. https://doi.org/10.1371/journal. ppat.1007440. [PubMed]

23. Mathewson ND, Fujiwara H, Wu SR, Toubai T, OraveczWilson K, Sun Y, Rossi C, Zajac C, Sun Y, Reddy P. SAG/ Rbx2-Dependent Neddylation Regulates T-Cell Responses. Am J Pathol. 2016; 186:2679-91. https://doi.org/10.1016/j. ajpath.2016.06.014. [PubMed]

24. Best S, Lam V, Liu T, Bruss N, Kittai A, Danilova OV, Murray S, Berger A, Pennock ND, Lind EF, Danilov AV. Immunomodulatory effects of pevonedistat, a NEDD8activating enzyme inhibitor, in chronic lymphocytic leukemia-derived T cells. Leukemia. 2021; 35:156-68. https://doi.org/10.1038/s41375-020-0794-0. [PubMed]

25. Friend SF, Peterson LK, Treacy E, Stefanski AL, Sosinowski T, Pennock ND, Berger AJ, Winn VD, Dragone LL. The discovery of a reciprocal relationship between tyrosinekinase signaling and cullin neddylation. PLoS One. 2013; 8:e75200. https://doi.org/10.1371/journal.pone.0075200. [PubMed]

26. Lu Y, Yang X. The pivotal roles of neddylation pathway in immunoregulation. Immun Inflamm Dis. 2020; 8:782-92. https://doi.org/10.1002/iid3.335. [PubMed]

27. Mathewson N, Toubai T, Kapeles S, Sun Y, Oravecz-Wilson K, Tamaki H, Wang Y, Hou G, Sun Y, Reddy P. Neddylation plays an important role in the regulation of murine and human dendritic cell function. Blood. 2013; 122:2062-73. https://doi.org/10.1182/blood-2013-02-486373. [PubMed]

28. Zhou L, Jiang Y, Liu X, Li L, Yang X, Dong C, Liu X, Lin Y, Li Y, Yu J, He R, Huang S, Liu G, et al. Promotion of tumor-associated macrophages infiltration by elevated neddylation pathway via NF-кB-CCL2 signaling in lung cancer. Oncogene. 2019; 38:5792-804. https://doi. org/10.1038/s41388-019-0840-4. [PubMed]
29. Gibson HM, Mishra A, Chan DV, Hake TS, Porcu P, Wong HK. Impaired proteasome function activates GATA3 in T cells and upregulates CTLA-4: relevance for Sézary syndrome. J Invest Dermatol. 2013; 133:249-57. https:// doi.org/10.1038/jid.2012.265. [PubMed]

30. Song N, Cao C, Tang Y, Bi L, Jiang Y, Zhou Y, Song X, Liu L, Ge W. The ubiquitin ligase SCFFBXW7 $\alpha$ promotes GATA3 degradation. J Cell Physiol. 2018; 233:2366-77. https://doi.org/10.1002/jep.26108. [PubMed]

31. Pearce EL, Poffenberger $\mathrm{MC}$, Chang $\mathrm{CH}$, Jones RG. Fueling immunity: insights into metabolism and lymphocyte function. Science. 2013; 342:1242454. https:// doi.org/10.1126/science.1242454. [PubMed]

32. Palazon A, Tyrakis PA, Macias D, Veliça P, Rundqvist H, Fitzpatrick S, Vojnovic N, Phan AT, Loman N, Hedenfalk I, Hatschek T, Lövrot J, Foukakis T, et al. An HIF-1 $\alpha /$ VEGF-A Axis in Cytotoxic T Cells Regulates Tumor Progression. Cancer Cell. 2017; 32:669-83.e5. https://doi.org/10.1016/j. ccell.2017.10.003. [PubMed]

33. Doedens AL, Phan AT, Stradner MH, Fujimoto JK, Nguyen JV, Yang E, Johnson RS, Goldrath AW. Hypoxia-inducible factors enhance the effector responses of CD8(+) T cells to persistent antigen. Nat Immunol. 2013; 14:1173-82. https:// doi.org/10.1038/ni.2714. [PubMed]

34. Filippova N, Yang X, An Z, Nabors LB, Pereboeva L. Blocking PD1/PDL1 Interactions Together with MLN4924 Therapy is a Potential Strategy for Glioma Treatment. J Cancer Sci Ther. 2018; 10:190-97. https://doi. org/10.4172/1948-5956.1000543. [PubMed]

35. Zhang J, Bu X, Wang H, Zhu Y, Geng Y, Nihira NT, Tan Y, Ci Y, Wu F, Dai X, Guo J, Huang YH, Fan C, et al. Cyclin D-CDK4 kinase destabilizes PD-L1 via cullin 3-SPOP to control cancer immune surveillance. Nature. 2018; 553:91-95. https://doi.org/10.1038/nature25015. [PubMed] 